\title{
Stock Plant Etiolation, Shading, and Banding Effects on Cutting Propagation of Carpinus betulus
}

\author{
Brian K. Maynard ${ }^{1}$ and Nina L. Bassuk \\ Department of Floriculture and Ornamental Horticulture, Cornell University, Ithaca, NY 14853
}

Additional index words. adventitious root formation, auxin, blanching, etiolation, upright European hornbeam

\begin{abstract}
In a study of stock plant etiolation and stem banding, stem cuttings of upright European hornbeam (Carpinus betulus L. 'Fastigiata') were taken at 2-week intervals over 4 months following budbreak and rooted under intermittent mist for 30 days. Percent rooting and root counts declined with increasing cutting age. Stock plant etiolation and stem banding increased percent rooting and root counts throughout the study, with the combination of both treatments yielding the best rooting. In nontreated stems, $>75 \%$ rooting was achieved only within 4 weeks of budbreak. Etiolation and stem banding resulted in rooting $\geq 75 \%$ up to 3 months after budbreak. In two shading studies, stock plants were grown in a glass greenhouse under $0 \%, 50 \%, 75 \%$, or $95 \%$ shade, or initially etiolated (100\% shade) for 1.5 days. Cuttings were taken after 2.5 and 60 days and treated with IBA concentrations ranging from 0 to $4.9 \mathrm{~mm}$ before rooting under intermittent mist for 30 days. Percent rooting increased proportionally to the degree of shading, with a maximum response at $95 \%$ shade. Cuttings taken at 60 days were less responsive to etiolation and shading than those harvested at 25 days. Auxin concentration interacted with shading to yield, at $95 \%$ shade and $3.7 \mathrm{~mm} \mathrm{IBA}$, the highest rooting percentage and the greatest root counts and lengths. Light exclusion by etiolation, stem banding, or shading can extend the cutting propagation season by increasing rooting responses and increasing the sensitivity of stem cuttings to exogenously applied auxin. Chemical name used: 1H-indole-3-butyric acid (IBA).
\end{abstract}

As a stock plant pretreatment to cutting propagation, etiolation involves excluding light during new shoot growth. Stem banding is a separate stock plant treatment that excludes light only from the section of stem that will become the cutting base. Stem banding makes use of a reusable, self-adhesive fabric (velcro) and has been shown, along with stock plant etiolation, to increase percent rooting, number of roots per rooted cutting, and rate of rooting in several difficult-to-root woody species (Maynard and Bassuk, 1987). Evidence also indicates that growing stock plants of woody species under reduced irradiance enhances the rooting of stem cuttings taken from these plants (Hansen, 1987). Shading stock plants markedly improved the rooting of Japanese maple (Acer palmatum Thunb.) (Behrens, 1988), border privet (Ligustrum obtusifolium Siebold \& Zucc.) (Knox and Hamilton, 1982), and silver linden (Tilia tomentosa Moench.) (Schmidt, 1982). Howard (1983, 1984) found that percent rooting and root count were proportional to shade level. The beneficial effect of stock plant shading on adventitious root initiation does not appear to be related to changes in spectral composition (Johnson and Roberts, 1971) or to alleviation of stock plant water stress (van den Driessche, 1985).

In a study of the interaction between stock plant irradiance and auxin application, Christensen et al. (1980) found that rooting percentages of Malling 26 (M.26) apple (Mulus pumila P. Mill.) rootstock cuttings decreased when grown at higher irradiance and that while auxin was of little benefit for high-irradiance stem cuttings, it stimulated rooting in moderate- and lowirradiance cuttings. Stromquist and Hansen (1980) studied the rooting of stem cuttings from seedlings of Scotch pine (Pinus sylvestris L.) in response to irradiance and concentration of applied IBA. Cuttings taken from seedlings grown under low irradiance rooted better and were more responsive to applied IBA. They concluded that although IBA improved the rooting of Scotch

Received for publication 22 May 1991. Accepted for publication 6 May 1992. The cost of publishing this paper was defrayed in part by the payment of page charges. Under postal regulations, this paper therefore must be hereby marked advertisement solely to indicate this fact.

'Present address: Dept. of Plant Sciences, The Univ. of Rhode Island, Kingston, RI 02881. pine, the response depended on the irradiance level for the stock plant.

Cuttings of European hornbeam are difficult to root, and variable rooting among cultivars has been noted (Dirr and Heuser, 1987). Etiolation and banding have been shown to improve the rooting of Carpinus and many other difficult-to-root species when cuttings are collected at a single harvest (Maynard and Bassuk, 1987). Therefore, the objectives of the first experiment were to determine how etiolation and stem banding affected rooting of stems of upright European hornbeam of increasing age after budbreak and how this affects the timing of taking cuttings. The objectives of a second experiment were to compare the use of shade with etiolation as a stock plant pretreatment, and to determine if shading interacts with auxin concentration to affect rooting response.

\section{Materials and Methods}

Stock plant culture. Twenty 5-year-old stock plants of upright European hornbeam-(Schichtel's Nursery, Orchard Park, N.Y.; grafted on seedling rootstock) were potted into 30-liter (Expt. 1) or 40-liter (Expt. 2) plastic containers using a medium of 1 sandy loam soil : 1 sphagnum peat : 1 perlite (by volume) and placed in lighted storage at $4 \pm 1 \mathrm{C}$ for 12 weeks before each experiment (Nov. 1987 and Nov. 1988 for Expts. 1 and 2, respectively). Following cold storage, plants were transferred to a glass greenhouse $(16 \pm 3 \mathrm{C}$ day/night). Incandescent lamps $(100-\mathrm{W})$, suspended $\approx 3 \mathrm{~m}$ above the stock plants and spaced 1 m apart, were used daily from 4:00 PM to 12:00 AM to extend the natural photoperiod to $\approx 16 \mathrm{~h}\left[\approx 2 \mu \mathrm{mol} \cdot \mathrm{m}^{-2} \cdot \mathrm{s}^{-1}\right.$ at midplant level measured using a LI-COR LI-190SB quantum sensor (LI-COR, Lincoln, Neb.; sensor error $\leq 0.1 \mu \mathrm{mol} \cdot \mathrm{m}^{-2} \cdot \mathrm{s}^{-1}$ )]. Stock plants were fertilized weekly with $200 \mathrm{mg} \mathrm{N} /$ liter from a 20N-4.4P-16.6K water-soluble fertilizer (Grace-Sierra, Milpitas, Calif.).

Etiolation and banding effects on rooting (Expt. 1). The 20 stock plants forced for Expt. 1 began to break bud within 1 week, at which time 10 of the plants were etiolated in a structure covered with black cloth, with 0.5 to $1.0 \mathrm{~m}$ between the plants and covering. Light-grown stock plants remained uncovered and 
grew under ambient irradiance. The etiolation structure excluded $>99 \%$ of incident visible radiation. Light was excluded from developing shoots until they were 5 to $10 \mathrm{~cm}$ long, which required 7 days. At this time, banding was applied to half of the shoots selected at random throughout the crown of each stock plant; the etiolation cover was removed gradually over the next 5 days. Stem banding involved sandwiching the base of new shoot growth between the "hook" and "wool" halves of $2.5 \times 2.5 \mathrm{~cm}$ strips of velcro, pressed on the stems so that they would not slip from position after application (Maynard and Bassuk, 1987). Light-grown and etiolated shoots were banded at the same time. In this experiment, the transition of etiolated to green growth, which occurred on exposure to light, is referred to as "greening." The beginning of the greening period coincided with the termination of the etiolation period: 7 days after budbreak. Therefore, light-grown shoots were exposed to ambient irradiance 7 days longer than etiolated shoots.

Cuttings were taken every 2 weeks, for 16 weeks from the start of the greening period, by severing shoots at the base of the new growth. Banded shoots were cut immediately proximal to the velcro band, and the bands were removed. Nonbanded cuttings were taken from positions throughout the stock plant crown and pruned to a length of 7 to $10 \mathrm{~cm}$, with three leaves per cutting (terminal growth removed). Cuttings were immersed for $10 \mathrm{~min}$ in an aqueous solution of 3a, 4, 7, 7a-tetrahydro-2[(trichloromethyl)thiol]-1H-isoindole-1,3(2H)-dione (Captan 50WP) at $0.25 \mathrm{~g} \cdot \operatorname{liter}^{-1}(\mathrm{w} / \mathrm{v})$, placed in polyethylene bags, and stored at $5 \pm 1 \mathrm{C}$ for $\approx 1 \mathrm{~h}$ before insertion into the rooting medium. The basal $1 \mathrm{~cm}$ of the prepared cuttings were then dipped for $5 \mathrm{sec}$ into $9.8 \mathrm{~mm} \mathrm{IBA}$ in $50 \%$ aqueous ethanol, allowed to air dry for $15 \mathrm{~min}$, and distributed randomly into eight replicate groups of seven cuttings each. Cuttings were inserted $\approx 2 \mathrm{~cm}$ deep in a completely randomized design into a raised greenhouse bench containing a $13-\mathrm{cm}$-deep unheated perlite rooting medium and were rooted under intermittent mist (6 sec every $8 \mathrm{~min}$ from 6:00 AM to 8:30 PM daily). A 16-h photoperiod was provided by $60-\mathrm{W}$ incandescent lamps suspended $1 \mathrm{~m}$ above the medium and spaced $1 \mathrm{~m}$ apart $\left(\approx 5 \mu \mathrm{mol} \cdot \mathrm{m}^{-2} \cdot \mathrm{s}^{-1}\right.$ additional irradiance at cutting level measured using a LI-COR LI-190SB quantum sensor). Air in the propagation house was at $20 \pm 5 \mathrm{C}$; cloth with $50 \%$ light transmission shaded the propagation benches.

Shading effects on rooting (Expt. 2). Stock plants forced for Expt. 2 began to break bud after 25 days. Following budbreak, plants to be etiolated or shaded were enclosed in structures covered with. black cloth or Chicopee shade cloth (Lumite, Gainesville, $\mathrm{Ga}$.), with 0.5 to $1.0 \mathrm{~m}$ separating the plants and coverings. Light-grown stock plants remained uncovered and grew under ambient irradiance ( $0 \%$ shade). Shading was arranged to exclude $50 \%$ (one layer $50 \%$ shade cloth), 75\% (two layers $50 \%$ shade cloth), $95 \%$ (one layer $95 \%$ shade cloth), or $>99 \%$ (black cloth) of ambient irradiance.

Light, temperature, and relative humidity $(\mathrm{RH})$ within enclosures used in Expt. 2 were monitored during etiolation using a CR21 datalogger (Campbell Scientific, Logan, Utah) equipped with a LI-190SB quantum sensor and model 207 temperature and relative humidity probe (Campbell Scientific; thermistor error $\leq 0.1 \mathrm{C}, \mathrm{RH}$ error $\leq 1 \%$ ) (Table 1$)$. Heat buildup during etiolation was reduced by covering the etiolation structure with white cloth. For the shading treatment, stock plants were shaded until cuttings were taken. Etiolation was applied only until developing shoots were 5 to $10 \mathrm{~cm}$ long, i.e., in 15 days. At this time, the black cloth was removed gradually over the next 3
Table 1. Conditions of light, temperature, and relative humidity associated with stock plant shading and etiolation of Carpinus betulus 'Fastigiata'. Diurnal conditions monitored using a CR21 datalogger during the period 23-28 Feb. 1989 in a glass greenhouse in Ithaca, N.Y. (latitude $42^{\circ} 25^{\prime} \mathrm{N}$ ).

\begin{tabular}{|c|c|c|c|c|c|c|}
\hline \multirow{2}{*}{$\begin{array}{l}\text { Shading } \\
\text { treatment }\end{array}$} & \multicolumn{2}{|c|}{$\begin{array}{c}\text { Irradiance } \\
\left(\mu \mathrm{mol} \cdot \mathrm{m}^{-2} \cdot \mathrm{s}^{-1}\right) \\
\end{array}$} & \multicolumn{2}{|c|}{$\begin{array}{l}\text { Temp } \\
\left({ }^{\circ} \mathrm{C}\right)\end{array}$} & \multicolumn{2}{|c|}{$\begin{array}{c}\text { Relative } \\
\text { humidity } \\
(\%)\end{array}$} \\
\hline & Mean & Maximum & Mean & Range & Mean & Range \\
\hline Etiolation & 0 & 3 & 16.2 & $11.8-26.5$ & 41 & $14-48$ \\
\hline $95 \%$ & 8 & 38 & 15.7 & $13.6-20.3$ & 47 & $31-63$ \\
\hline $75 \%$ & 36 & 274 & 16.1 & $12.3-31.2$ & 40 & $22-64$ \\
\hline $50 \%$ & 70 & 664 & 16.3 & $12.3-33.7$ & 37 & $22--55$ \\
\hline Light-grown & 134 & 1140 & 15.5 & $11.8-28.5$ & 46 & $2-84$ \\
\hline
\end{tabular}

days, and etiolated shoots were allowed to green without shading until cuttings were taken for rooting.

Cuttings were taken 25 and 60 days after budbreak (10 and 45 days after etiolation ended) by severing shoots at the base. of the new growth. The basal $1 \mathrm{~cm}$ of the cuttings was dipped for $5 \mathrm{sec}$ into $4.9 \mathrm{~mm}$ IBA in $50 \%$ aqueous ethanol, allowed to air dry for $15 \mathrm{~min}$, and distributed randomly into eight replicate groups of eight cuttings each before being inserted into the rooting medium. Cuttings collected for the auxin-dose trials were taken 60 days after budbreak. The basal $1 \mathrm{~cm}$ was dipped for $5 \mathrm{sec}$ into $0,1.2,2.5,3.7$, or $4.9 \mathrm{~mm}$ IBA in $50 \%$ aqueous ethanol and distributed into six groups of five cuttings each. All other cutting treatments were as described for Expt. 1.

Recording of data and statistical analysis. Cuttings were evaluated after 30 days for percent rooting, number of roots per rooted cutting, and root length (measured from point of emergence). A cutting was considered rooted if it possessed one or more roots $>1 \mathrm{~mm}$ long. Data of Expt. 1 were analyzed as a 2 $\times 2$ factorial of etiolation and banding treatments at each greening time (analyses not presented) (SAS, 1985). Protected least significant differences were calculated across greening times and treatments to simplify presentation of variance. Data of Expt. 2 were analyzed using linear regression of the $0 \%$ to $95 \%$ shade level responses. Shade by dose-response data were analyzed as a response surface. In Expt. 2, etiolation was evaluated only as an initial stock plant treatment because etiolated growth needed to green before being used as cutting material to avoid injury from high light intensity or desiccation. Hence, the responses of cuttings taken from initially etiolated shoots were not included in regressions of rooting on shade level. Responses of etiolated cuttings were compared with those of shaded cuttings using a two-sample unpaired t test. Percentage data were arcsin-transformed before analysis (Snedecor and Cochran, 1980).

\section{Results}

Etiolation and banding effects on rooting (Expt. 1). Percent rooting of light-grown, nonbanded cuttings declined from an initial high of $88 \%$ to $0 \%$ after 16 weeks of greening (17 weeks post-budbreak) (Table 2). Only light-grown, banded cuttings showed increased rooting at the first harvest date ( 2 weeks). By 4 weeks of greening time, etiolated shoots were rooting 10 percentage points better on average than light-grown shoots. After 6 to 8 weeks, etiolation and banding improved rooting by an average of 30 percentage points over the light-grown and 12 percentage points over the nonbanded responses, respectively. Etiolation increased percent rooting between 4 and 12 weeks after etiolation ceased. The banding effect was less dramatic 
Table 2. Rooting response of stem cuttings of Carpinus betulus 'Fastigiata' to greening time, stock plant etiolation, and stem banding treatments (Expt. 1). Etiolation was applied for 7 days and banding with velcro for 2 to 16 weeks. Light-grown shoots were exposed to ambient irradiance 7 days longer than initially etiolated shoots. The basal $1 \mathrm{~cm}$ of cuttings was dipped for $5 \mathrm{sec}$ into $9.8 \mathrm{~mm}$ IBA and rooted in perlite under intermittent mist. Percent rooting, mean number of roots per cutting, and mean root length were recorded after 30 days. Mean percent rooting was based on eight replicates of seven cuttings each.

\begin{tabular}{|c|c|c|c|c|c|c|c|c|}
\hline & \multicolumn{8}{|c|}{ Greening time (weeks) } \\
\hline & 2 & 4 & 6 & 8 & 10 & 12 & 14 & 16 \\
\hline & \multicolumn{8}{|c|}{ Rooting (\%) } \\
\hline $\mathrm{LG}^{\mathbf{z}}$, - band & 88 & 82 & 50 & 69 & 46 & 17 & 7 & 0 \\
\hline $\mathrm{LG},+$ band & 98 & 87 & 71 & 81 & 48 & 38 & 7 & 7 \\
\hline ET, - band & 91 & 93 & 88 & 90 & 70 & 41 & 8 & 1 \\
\hline \multirow{3}{*}{$\begin{array}{l}\mathrm{ET},+ \text { band } \\
\mathrm{LSD}_{0.05}=9\end{array}$} & 91 & 97 & 90 & 98 & 75 & 89 & 28 & 16 \\
\hline & & & & & & & & \\
\hline & \multicolumn{8}{|c|}{ Roots/rooted cutting } \\
\hline LG, - band & 4 & 3 & 3 & 4 & 3 & 2 & 2 & $\ldots$ \\
\hline $\mathrm{LG},+$ band & 6 & 6 & 4 & 4 & 3 & 6 & 2 & 2 \\
\hline $\mathrm{ET}$, - band & 5 & 5 & 7 & 4 & 3 & 3 & 2 & 1 \\
\hline \multirow{3}{*}{$\begin{array}{l}\mathrm{ET},+ \text { band } \\
\mathrm{LSD}_{0.05}=2\end{array}$} & 7 & 8 & 7 & 7 & 4 & 5 & 4 & 3 \\
\hline & & & & & & & & \\
\hline & \multicolumn{8}{|c|}{ Root length $(\mathrm{mm})$} \\
\hline LG, - band & 1 & 1 & 2 & 3 & 15 & 16 & 11 & 10 \\
\hline $\mathrm{LG},+$ band & 2 & 2 & 3 & 7 & 12 & 22 & 20 & 12 \\
\hline ET, - band & 1 & 1 & 2 & 3 & 11 & 14 & 13 & 11 \\
\hline $\mathrm{ET}$, + band & 2 & 2 & 4 & 5 & 14 & 25 & 29 & 17 \\
\hline $\mathrm{LSD}_{0.05}=5$ & & & & & & & & \\
\hline
\end{tabular}

${ }^{7} \mathrm{LG}=$ light-grown, $\mathrm{ET}=$ etiolated.

'Means based on actual number of cuttings that rooted.

No cuttings rooted.

than that of etiolation and yet, after 12 weeks, yielded increases of up to 48 percentage points. Cuttings taken from shoots receiving both etiolation and stem banding yielded the highest percent rooting after $\geq 12$ weeks of greening. This combination yielded $89 \%$ rooting after 12 weeks of greening, in which time rooting of light-grown, nonbanded shoots had decreased to $<20 \%$. Considered at individual harvest dates, etiolation alone improved rooting by up to 38 percentage points ( 6 weeks), banding alone improved it by up to 21 percentage points (6 and 12 weeks), and etiolation plus banding by up to 72 percentage points (12 weeks) compared with light-grown, nonbanded controls. Across all harvest dates, etiolation improved rooting by an average of 17 percentage points, and banding improved rooting by an average of 11 percentage points $(P=0.001$ each). Etiolation and banding effects did not appear to interact $(P=$ 0.38 ) and were even additive, yielding an average increase of 29 percentage points when both treatments were applied.

The number of roots per rooted cutting of light-grown, nonbanded shoots ranged from four initially to only two after 14 weeks of greening (Table 2). Root counts generally declined after 8 weeks of greening. Etiolation alone increased root counts only after 4 and 6 weeks of greening. Banding alone increased root counts in weeks 2, 4, and 12. Etiolation and banding combined yielded the highest root counts across much of the greening period. As observed with percent rooting, etiolation and banding effects did not interact. Across all harvest dates, etiolated and banded shoots produced a mean of six roots per rooted cutting compared with three for light-grown, nonbanded controls.
Across all stock plant treatments, roots were shorter on cuttings taken within 8 weeks of budbreak $(3 \pm 0.9 \mathrm{~mm})$ than later on. Mean root length increased to $13 \pm 0.9 \mathrm{~mm}$ within 10 weeks and peaked at $19 \pm 2.5 \mathrm{~mm}$ on cuttings taken 12 weeks after budbreak (Table 2). Stem banding had increased root length by 12 to 14 weeks. Stock plant etiolation did not initially affect root length, but, in combination with banding, promoted longer roots at 14 and 16 weeks after the end of treatment, when root length on most cuttings had begun to decline. This experiment was repeated in 1989 with similar results (data not presented).

Shading effects on rooting (Expt. 2). Percent rooting of cuttings from shoots grown for 2.5 or 60 days increased with the degree of shading (Table 3). At both harvests, etiolated shoots had rooted better than those from $0 \%$ and $50 \%$ shade $(P<$ 0.001 each) and better than those from $75 \%$ shade after 25 days greening $(P<0.001)$.

The number of roots per cutting also increased with increasing shade level, to a maximum at $75 \%$ shade (Table 3 ). Cuttings of etiolated shoots greened for 45 days (60 days harvest date) produced fewer roots $(P=0.01)$ than those from stock plants in $75 \%$ or $95 \%$ shade, but more roots than those from lightgrown shoots $(0 \%$ shade; $P=0.02)$. Mean root length was 2 $\pm 0.1 \mathrm{~mm}$ on both 25 - and 60-day cuttings and was not affected by shading or etiolation.

Percent rooting also increased in response to the combination of increasing levels of shade and auxin (Table 4). Increasing shade increased response of the cuttings to exogenously applied auxin, while a shade effect was evident only when cuttings were treated with concentrations of IBA $22.5 \mathrm{~mm}$. The difference between the no-auxin response and the maximum rooting re-

Table 3. Rooting response of stem cuttings of Carpinus betulus 'Fastigiata' to stock plant shading (Expt. 2). Etiolation was applied for 15 days followed by greening; other shading treatments were continuous until cuttings were taken, 25 or 60 days after budbreak. The basal $1 \mathrm{~cm}$ of cuttings was dipped for $5 \mathrm{sec}$ into $4.9 \mathrm{~mm}$ IBA and rooted in perlite under intermittent mist. Percent of rooting and mean number of roots per rooted cutting were recorded after 30 days. Mean percent rooting was based on eight replicates of eight cuttings each.

\begin{tabular}{|c|c|c|c|c|c|}
\hline \multirow[b]{2}{*}{ Harvest time } & \multicolumn{5}{|c|}{ Degree of shading (\%) for stock plants } \\
\hline & 0 & 50 & 75 & 95 & Etiolated \\
\hline \multirow{3}{*}{$\begin{array}{l}25 \text { days } \\
60 \text { days }\end{array}$} & \multicolumn{5}{|c|}{ Rooting (\%) } \\
\hline & 11 & 73 & 70 & 98 & 92 \\
\hline & 31 & 55 & 75 & 92 & 77 \\
\hline & \multicolumn{5}{|c|}{ Roots/rooted cuttingy } \\
\hline 25 days & 2 & 3 & 4 & 3 & 3 \\
\hline 60 days & 2 & 3 & 4 & 4 & 3 \\
\hline \multicolumn{2}{|l|}{ ANOVA } & \multicolumn{4}{|c|}{ Significance } \\
\hline \multicolumn{2}{|l|}{ Source } & \multicolumn{2}{|c|}{$\begin{array}{c}\text { Rooting } \\
(\%)\end{array}$} & \multicolumn{2}{|c|}{$\begin{array}{c}\text { Roots/rooted } \\
\text { cutting }\end{array}$} \\
\hline \multicolumn{2}{|l|}{ Harvest time } & \multirow{3}{*}{\multicolumn{2}{|c|}{$\begin{array}{l}0.11 \\
0.0001\end{array}$}} & \multicolumn{2}{|c|}{0.03} \\
\hline \multirow{2}{*}{\multicolumn{2}{|c|}{$\begin{array}{l}\text { Shade level } \\
25 \text { days }\end{array}$}} & & & \multicolumn{2}{|c|}{0.009} \\
\hline & & & & \multirow{2}{*}{\multicolumn{2}{|c|}{0.02}} \\
\hline $\mathrm{L}^{\mathrm{x}}$ & & \multicolumn{2}{|c|}{0.0001} & & \\
\hline 60 days & & \multicolumn{2}{|c|}{0.27} & \multicolumn{2}{|c|}{0.01} \\
\hline $\mathrm{L}$ & & \multicolumn{2}{|c|}{0.0001} & \multicolumn{2}{|c|}{0.0001} \\
\hline Q & & \multicolumn{2}{|c|}{0.57} & \multicolumn{2}{|c|}{0.06} \\
\hline Time $\times$ shade & & \multicolumn{2}{|c|}{0.05} & \multicolumn{2}{|c|}{0.007} \\
\hline
\end{tabular}

${ }^{2}$ Response of cuttings from etiolated shoots not included in ANOVA. 'Means based on actual number of cuttings that rooted. ${ }^{\mathrm{x}} \mathrm{L}=$ linear, $\mathrm{Q}=$ quadratic. 
Table 4. Percent rooting of stem cuttings of Carpinus betulus 'Fastigiata' as influenced by IBA concentration and stock plant shading (Expt. 2). Etiolation was applied for 15 days following budbreak, followed by greening in full sun for 45 days. Shade levels expressed as percent of ambient light excluded. The basal $1 \mathrm{~cm}$ of cuttings was dipped for $5 \mathrm{sec}$ into IBA and rooted in perlite under intermittent mist. Percent rooting was evaluated after 30 days rooting. Means based on six replicates of five cuttings each.

\begin{tabular}{|c|c|c|c|c|c|}
\hline \multirow[b]{2}{*}{ IBA $(\mathrm{mM})$} & \multicolumn{5}{|c|}{ Degree of shading (\%) for stock plants } \\
\hline & 0 & 50 & 75 & 95 & Etiolated $^{2}$ \\
\hline 0.0 & 0 & 0 & 3 & 7 & 0 \\
\hline 1.2 & 17 & 20 & 15 & 20 & 7 \\
\hline 2.5 & 3 & 30 & 37 & 60 & 33 \\
\hline 3.7 & 37 & 50 & 57 & 90 & 62 \\
\hline 4.9 & 40 & 50 & 75 & 67 & 78 \\
\hline ANOVA & \multicolumn{5}{|c|}{ Significance } \\
\hline Source & \multicolumn{5}{|c|}{$\begin{array}{c}\text { Rooting } \\
(\%)\end{array}$} \\
\hline Shade level & \\
\hline $\mathrm{L}^{y}$ & \multicolumn{5}{|c|}{0.49} \\
\hline$Q$ & \multicolumn{5}{|c|}{0.19} \\
\hline IBA & & & & & \\
\hline $\mathrm{L}$ & \multicolumn{5}{|c|}{0.002} \\
\hline $\bar{Q}$ & \multicolumn{5}{|c|}{0.16} \\
\hline Shade $\times$ IBA & \multicolumn{5}{|c|}{0.004} \\
\hline
\end{tabular}

${ }^{2}$ Response of cuttings from etiolated shoots not included in ANOVA. ${ }^{y} \mathrm{~L}=$ linear, $\mathrm{Q}=$ quadratic.

sponse increased with degree of shading, e.g., 40 percentage points at $0 \%$ shading, 50 percentage points at 50\% shading, 72 percentage points at $75 \%$ shading, and 83 percentage points at $95 \%$ shading. Only $67 \%$ of cuttings taken from plants grown in $95 \%$ shade and treated with $4.9 \mathrm{~mm}$ IBA rooted (Table 4), in contrast with the initial shading study, in which $92 \%$ of 60 dayold cuttings collected from $95 \%$ shade-grown plants and treated with $4.9 \mathrm{~mm}$ IBA rooted (Table 3 ). The rooting of etiolated shoots increased by 78 percentage points at the highest IBA concentration applied. The IBA response of etiolated shoots was linear $(P=0.008)$ and reached a smaller $(\mathrm{P}=0.03)$ maximum response than that of shoots from $95 \%$ shade but a greater $(P$ $=0.001$ ) maximum response than light-grown shoots.

The highest root counts and longest roots occurred on cuttings taken from stock plants grown under $95 \%$ shade and treated with 3.7 mM IBA (Table 5). Root counts of shaded cuttings generally peaked with $3.7 \mathrm{~mm}$ IBA. Root lengths increased quadratically with shade level and peaked at $3.7 \mathrm{~mm}$ IBA for all except $75 \%$ shade-grown cuttings. Root counts and lengths of initially etiolated cuttings were again reduced compared with cuttings from plants grown under $95 \%$ shade, and root lengths did not vary significantly with IBA level. There were no interactions between shade level and auxin concentration with respect to root count and length.

\section{Discussion}

When propagating many difficult-to-root species, the seasonal timing for taking cuttings is critical. For some species, a high percentage of rooting might be achieved for a short time following budbreak and thereafter decline, until by autumn little or no rooting occurs (Wells, 1985). This response is typified in the present study by the rooting of cuttings prepared from lightgrown, nonbanded shoots, which was highest within 1 month of budbreak. The most roots also were produced on cuttings taken within 8 weeks of budbreak. Stock plant etiolation and
Table 5. Root numbers and root lengths of stem cuttings of Carpinus betulus 'Fastigiata' as influenced by IBA concentration and stock plant shading (Expt. 2). Etiolation was applied for 15 days following budbreak, followed by greening in full sun for 45 days. Shade levels expressed as percent of ambient light excluded. The basal $1 \mathrm{~cm}$ of cuttings was dipped for $5 \mathrm{sec}$ into IBA and rooted in perlite under intermittent mist. Mean number of roots per rooted cutting and mean root length (millimeters), in parentheses, were evaluated after 30 days of rooting. Means based on actual numbers of cuttings that rooted.

\begin{tabular}{|c|c|c|c|c|c|}
\hline \multirow[b]{2}{*}{ IBA (mM) } & \multicolumn{5}{|c|}{ Degree of shading (\%) for stock plants } \\
\hline & 0 & 50 & 75 & 95 & Etiolated ${ }^{\mathrm{z}}$ \\
\hline 0.0 & $---y$ & --- & $1(1)$ & $2(1)$ & -- \\
\hline 1.2 & $2(1)$ & $1(1)$ & $1(4)$ & $1(5)$ & $1(1)$ \\
\hline 2.5 & 1(1) & $2(2)$ & $1(2)$ & $2(5)$ & $1(2)$ \\
\hline 3.7 & $2(2)$ & $2(2)$ & $3(3)$ & $4(6)$ & $3(2)$ \\
\hline 4.9 & $3(2)$ & $2(2)$ & $2(2)$ & $3(5)$ & $3(2)$ \\
\hline \multicolumn{2}{|c|}{ ANOVA } & & \multicolumn{2}{|c|}{ Significance } & \\
\hline Source & & & $\begin{array}{l}\text { Roots/rooted } \\
\text { cutting } \\
\end{array}$ & $\begin{array}{l}\text { Root } \\
\text { length }\end{array}$ & \\
\hline \multicolumn{6}{|l|}{ Shade level } \\
\hline$L^{x}$ & & - & 0.08 & 0.86 & \\
\hline $\bar{Q}$ & & & 0.05 & 0.011 & \\
\hline \multicolumn{6}{|l|}{ IBA } \\
\hline $\mathrm{L}$ & & & 0.05 & 0.017 & \\
\hline$Q$ & & & 0.06 & 0.016 & \\
\hline Shade $\times$ IBA & & & 0.19 & 0.47 & \\
\hline
\end{tabular}

${ }^{\mathrm{T}}$ Response of cuttings from etiolated shoots not included in ANOVA. No cuttings rooted.

${ }^{x} \mathrm{~L}=$ linear, $\mathrm{Q}=$ quadratic.

stem banding increased percent rooting, root count, and root length up to 4 months after etiolation ended. Furthermore, stem banding increased rooting within 14 days of application. Stock plant treatment effects on root length were not apparent until 8 to 12 weeks after budbreak. While rooting data were recorded in both experiments after 30 days, the short root lengths we observed suggest that longer rooting periods would be desirable.

Etiolated shoots turn green within a few days of exposure to light, yet percent rooting of cuttings prepared from initially etiolated shoots declines over a period of months (HarrisonMurray and Howard, 1982). It has been shown that up to 3 to 6 weeks of greening after etiolation causes no decrease in rooting (Howard, 1980; Schmidt, 1982). We observed this effect after 8 weeks of greening. Moreover, 9 months of light exposure to initially etiolated M.9 apple rootstock shoots decreased the percentage of rooting to a level still $40 \%$ above that of nonetiolated shoots (Howard, 1982, 1983). The fact that initial exclusion of light from developing stems has a residual effect on rooting suggests that developmental changes beneficial to rooting occur in stem tissues differentiating in the absence of light. Several studies have shown that initial etiolation or stem banding delays the lignification of stems of camphor tree [Cinnamomum camphora (L.) J. Presl.] (Reid, 1923), European chestnut (Custanea sativa Mill.) (Rinallo et al., 1987) and silver linden (Schmidt, 1986). Initial etiolation delayed sclerid formation in stems of Carpinus by up to 8 weeks (Maynard, 1990).

Our results indicate that rooting also increased with decreasing level of stock plant irradiance, across a range of auxin concentrations. As shown with M.26 apple (Christensen et al., 1980), cuttings from shaded stock plants were more responsive to exogenously applied auxin. In contrast with the rooting response to $95 \%$ shading, the rooting of initially etiolated shoots appears 
to have been reduced by exposure of the shoots to light before propagation. Commercial application of stock plant etiolation to vegetative propagation by stem cuttings may be limited because the etiolation structure can allow heat and humidity to build up around the delicate new growth contained within, yielding favorable conditions for the growth of pathogenic fungi (Howard, 1982). In the present experiment, changes in temperature or RH with the shading or etiolation treatments were kept to a minimum (Le., within $1 \mathrm{C}$ and $10 \% \mathrm{RH}$; Table 1), and apparently had no effect on rooting response. The effect of ambient air temperature on subsequent rooting has not been studied extensively and is thought to play a minor role in rooting (Moe and Anderson, 1988). Toward developing commercial methods of modifying stock plant irradiance for improved rooting of cuttings, allowing some light to reach the stock plant during treatment creates a significant advantage in terms of improved plant health and ease of propagation. Shoots grown in 95\% shade did not appear etiolated and may be maintained in shade up to the time of harvest, without the need for light acclimation before propagation.

\section{Literature Cited}

Behrens, V. 1988. Influence of light intensity on the propagation success of Acer palmatum 'Atropurpureum' propagated by cuttings. Acta Hort. 226:321-326.

Christensen, M.V., E.N. Eriksen, and A.S. Andersen. 1980. Interaction of stock plant irradiance and auxin in the propagation of apple rootstocks by cuttings. Scientia Hort. 12:11-17.

Dirr, M.A. and C.W. Heuser, Jr. 1987. The reference manual of woody plant propagation: From seed to tissue culture. Varsity Press, Athens, Ga.

Hansen, J. 1987. Stock plant lighting and adventitious root formation. HortScience 22:746-749.

Harrison-Murray, R.S. and B.H. Howard. 1982. Effects of prior etiolation on adventitious rooting of apple cuttings. Proc. Intl. Soc. Hort. Sci., 21st Intl. Hort. Congr., Hamburg, Germany. vol. 1, Abstr. 1281.

Howard, B.H. 1980. Plant propagation. Rpt. E. Mailing Res. Sta. for 1979. p. 67-84.

Howard, B.H. 1982. Plant propagation. Rpt. E. Malling Res. Sta. for 1981. p. $57-72$.
Howard, B.H. 1983. Plant propagation. Rpt. E. Malling Res. Sta. for 1982. p. 59-75.

Howard, B.H. 1984. Plant propagation. Rpt. E. Malling Res. Sta. for 1982. p. 77-91.

Johnson, C.R. and A.N. Roberts. 1971. The effect of shading Rhododendron stock plants on flowering and rooting. J. Amer. Soc. Hort. Sci. 96:166-168.

Knox, G.W. and D.F. Hamilton. 1982. Rooting of Berberis and $\mathrm{Li}$ gustrum cuttings from stock plants grown at selected light intensities. Scientia Hort. 16:85-90.

Maynard, B.K. 1990. Physiological and anatomical factors associated with the etiolation response in cutting propagation. PhD Diss., Cornell Univ., Ithaca, N.Y.

Maynard, B.K. and N.L. Bassuk. 1987. Stock plant etiolation and blanching of woody plants prior to cutting propagation. J. Amer. Soc. Hort. Sci. 112:273-276.

Moe, R. and A.S. Andersen. 1988. Stock plant environment and subsequent adventitious rooting, p. 214-234. In: T.D. Davis, B.E. Haissig, and N. Sankhla (eds.). Adventitious root formation in cuttings. Dioscorides Press, Portland, Ore.

Reid, 0. 1923. The propagation of camphor by stem cuttings. Trans. Proc. Bot. Soc. Edinburgh 28:184-188.

Rinallo, C., R. Gellini, and A. Fabbri. 1987. Studies on rhizogenesis in Castanea sativa Mill. cuttings. Adv. Hort. Sci. 1:27-33.

SAS. 1985. SAS user's guide: Statistics. 5th ed. SAS Institute, Cary, N.C.

Schmidt, G. 1982. Different methods of etiolation for increasing the rooting of the silver lime, Tilia tomentosa, softwood cuttings. Proc. Intl. Soc. Hort. Sci., 21st Intl. Hort. Congr., Hamburg, Germany. vol. 2, Abstr. 1785.

Schmidt, G. 1986. Effect of etiolation on the histological structure of the stem of Tilia tomentosa Moench. Folia Dendro. 13:217-262.

Snedecor, G.W. and W.G. Cochran. 1980. Statistical methods. 7th ed. The Iowa State Univ. Press, Ames.

Stromquist, L.H. and J. Hansen. 1980. Effects of auxin and irradiance on the rooting of cuttings of Pinus sylvestris. Physiol. Plant. 49:346350 .

van den Driessche, R. 1985. The influence of cutting treatments with indole-3-butyric acid and boron, stock plant moisture stress, and shading on rooting in Sitka spruce. Can. J. For. Res. 15:740-742.

Wells, J.S. 1985. Plant propagation practices. Amer. Nurseryman Publishing, Chicago. 